\title{
Wheat Genotype-Specific Induction of Soil Microbial Communities Suppressive to Disease Incited by Rhizoctonia solani Anastomosis Group (AG)-5 and AG-8
}

\author{
Mark Mazzola and Yu-Huan Gu
}

U.S. Department of Agriculture-Agricultural Research Service, Tree Fruit Research Laboratory, 1104 N. Western Avenue, Wenatchee, WA 98801.

Accepted for publication 24 July 2002.

\begin{abstract}
Mazzola, M., and Gu, Y.-H. 2002. Wheat genotype-specific induction of soil microbial communities suppressive to disease incited by Rhizoctonia solani anastomosis group (AG)-5 and AG-8. Phytopathology 92:13001307.

The induction of disease-suppressive soils in response to specific cropping sequences has been demonstrated for numerous plant-pathogen systems. The role of host genotype in elicitation of the essential transformations in soil microbial community structure that lead to disease suppression has not been fully recognized. Apple orchard soils were planted with three successive 28-day cycles of specific wheat cultivars in the greenhouse prior to infestation with Rhizoctonia solani anastomosis group (AG)-5 or AG-8. Suppressiveness to Rhizoctonia root rot of apple caused by the introduced isolate of $R$. solani AG-5 was induced in a wheat cultivar-specific manner. Pasteurization of soils after wheat cultivation and prior to pathogen introduction eliminated the disease

suppressive potential of the soil. Wheat cultivars that induced disease suppression enhanced populations of specific fluorescent pseudomonad genotypes with antagonistic activity toward $R$. solani AG-5 and AG-8, but cultivars that did not elicit a disease suppressive soil did not modify the antagonistic capacity of this bacterial community. When soils were infested prior to the initial wheat planting, all cultivars were uniformly susceptible to $R$. solani AG- 8 . However, when pathogen inoculum was added after three growth-cycles, wheat root infection during the fourth growth-cycle varied in a cultivar specific manner. The same wheat cultivar-specific response in terms of transformation of the fluorescent pseudomonad community and subsequent suppression of Rhizoctonia root rot of apple was observed in three different orchard soils. These results demonstrate the importance of host genotype in modification of indigenous saprophytic microbial communities and suggest an important role for host genotype in the success of biological control.
\end{abstract}

Suppressive soils have been described for a number of soilborne plant pathogens and pests including various formae specialis of Fusarium oxysporum (34,41), Gaeumannomyces graminis var. tritici (6,36), Phytophthora cinnamomi (3), Pythium spp. (12), Heterodera avenae $(16,44)$, Streptomyces scabies (31), and Ralstonia solanacearum (35) among others. A desire to exploit disease-suppressive soils as a means to control soilborne plant pathogens stimulated studies of the soil properties and biological mechanisms that contribute to disease suppression. The study of these soils has yielded extensive knowledge concerning the abiotic and biotic mechanisms involved in disease suppression, and the identification of a vast pool of microbial resources that have shown potential as biological control agents.

Soils suppressive to Rhizoctonia solani also have been documented in response to successive plantings of a given plant host. Henis et al. (13) observed the development of suppressiveness after four to five successive plantings of radish, but observed no correlation between the onset of suppressiveness and relative in vitro antagonism of $R$. solani by the resident soil microflora. However, suppressive soils possessed higher populations of Trichoderma spp. than the corresponding conducive soil. Liu and Baker (24) identified Trichoderma harzianum as the primary cause of the disease decline in these soils. Chet and Baker (5) demonstrated that soil $\mathrm{pH}$ had an indirect influence on the phenomenon through

Corresponding author: M. Mazzola; E-mail address: mazzola@tfrl.ars.usda.gov

Publication no. P-2002-1002-01R

This article is in the public domain and not copyrightable. It may be freely reprinted with customary crediting of the source. The American Phytopathological Society, 2002. its impact on T. harzianum; growth and spore germination of $T$. harzianum was stimulated at low $\mathrm{pH}$ and suppressiveness to $R$. solani was induced by crop monoculture only in acidified or naturally acidic soils.

A soil suppressive to Rhizoctonia root rot of apple was recently identified in Washington (28). The soil had been in continuous wheat monoculture prior to planting apple at the site, and the microbial community resident in these soils became conducive to Rhizoctonia within 3 years of orchard establishment. The transition of the soil from a suppressive to conducive state was associated with significant changes in microbial community structure including a decrease in recovery of actinomycetes and Burkholderia cepacia from apple. In addition, a transformation of the fluorescent pseudomonad population was observed; dominated by Pseudomonas putida prior to planting apple but subsequently composed primarily of $P$. syringae and $P$. fluorescens bv. III in the conducive soil. Certain isolates of $P$. putida from these soils provided biological control of $R$. solani anastomosis group (AG)-5 (10,27).

The transfer or management of the biologically complex components that contribute to disease-suppressive soils in agricultural production systems is often a prominent goal of research programs. Typically, induction of disease-suppressive soils is achieved through multiple years of crop monoculture with several classic examples including potato scab decline (31), take-all decline (36), and cyst nematode decline (8). However, the duration of crop monoculture required to induce disease suppression is not a practical management tool in commercial production systems. Management practices, including crop rotation (15), input system (organic versus conventional; 42,45), tillage, and fertilization (14, 38 , influence ecological processes that impact microbial communities involved in suppression of soilborne plant pathogens. 
Through the integration of multiple strategies, it may be possible to stimulate transformation of a soil microbial community to a suppressive state within a time period suitable for incorporation into commercial agricultural production systems. The induction of disease-suppressive soils through crop monoculture or specific cropping sequences demonstrates the plants' role in the development of a disease suppressive soil microflora. A genetic basis for interactions between a plant host and a biocontrol rhizobacterium has also been observed (40). Thus, it is plausible that the host genotype may have a significant impact on the rate of change in composition of the soil microflora, and ultimately the degree of disease suppression achieved. Interestingly, Larkin et al. (19) demonstrated that a Fusarium wilt suppressive state could be achieved in soils through successive plantings of watermelon, however the response was limited to specific cultivars. Prior cultivation of wheat in orchard replant soils enhanced subsequent growth of apple, but the degree of growth improvement varied with the wheat cultivar that preceded apple (30).

The Rhizoctonia-suppressive soil described by Mazzola (28) had been in wheat monoculture prior to apple orchard establishment. The transient nature of Rhizoctonia-suppression observed was the impetus for studies to examine the use of wheat cover cropping as a means to reestablish a disease-suppressive microbial community in orchard replant soils. The objective of this study was to determine whether induction of a Rhizoctonia-suppressive soil is dependent on the wheat cultivar employed, whether disease suppression functions through activity of the soil microbial community, and if it is associated with transformations in the fluorescent pseudomonad community.

\section{MATERIALS AND METHODS}

Wheat cultivars and orchard soils. Wheat used in these studies included cvs. Eltan, Hill-81, Lewjain, Madsen, and Penawawa. All cultivars are soft white winter wheat, with the exception of 'Penawawa', which is a soft white spring wheat. Nontreated seed of each variety was obtained from the Washington State Crop Improvement Association, Foundation Seed Service, Washington State University, Pullman. Studies were conducted in replant soils obtained from the Columbia View Experimental (CV), Wenatchee Valley College-Auvil Research and Demonstration (WVC-A), and Wenatchee Valley College-Sunnyslope Demonstration (WVC-SS) orchards. Soil properties, collection methods, and composition of the pathogen complex at the respective sites have been described $(26,28)$.

Impact of wheat cultivation on suppression of Rhizoctonia solani AG-5. Orchard soils were collected in April and October 2001 and stored at $4^{\circ} \mathrm{C}$ no longer than 3 weeks prior to use. Orchard soils were placed in plastic trays $(50 \mathrm{~cm}$ long, $40 \mathrm{~cm}$ wide, $15 \mathrm{~cm}$ deep) and planted to an individual wheat cultivar. Wheat was sown in four rows with $8 \mathrm{~cm}$ between rows with a total of $70 \mathrm{~g}$ of seed per tray. Plants were grown for 28 days in the greenhouse at 18 to $22^{\circ} \mathrm{C}$ with supplemental lighting to maintain a minimum photoperiod of $12 \mathrm{~h}$. At the end of the 28-day growth cycle, plant shoots were excised at the soil surface and discarded. All soils, including controls, were cultivated by hand to disrupt the wheat root system and prepare a suitable seedbed. Soils were replanted to the same wheat cultivar. A total of three wheat growth-cycles, each of 28 days duration, were used in all experiments. During the period of wheat growth, noncultivated orchard soil was incubated in plastic trays on a greenhouse bench under the same environmental conditions. Plants were watered as needed with tap water, and fertilizer was not applied during the course of the experiment. At the conclusion of the wheat growth-cycles, a portion of the soil from each tray that had been cultivated to 'Penawawa' was pasteurized twice at $95^{\circ} \mathrm{C}$ for $4 \mathrm{~h}$ with a $24-\mathrm{h}$ period between treatments, and all soils were sampled after the second pasteurization treatment. 'Penawawa'-cultivated soils were selected for pasteurization due to the superior growth performance of apple relative to that observed in the same soils cropped to other wheat cultivars (30). For each treatment, moist soils were divided into six equal samples (three per tray) and $5 \mathrm{~g}$ of soil was collected from each sample for analysis of fluorescent Pseudomonas spp. populations.

Induction of seed germination and production of 'Gala' apple seedlings used in these studies were conducted as previously described (30). Seedlings were grown in controlled environment chambers at $24^{\circ} \mathrm{C}$ with a 12 -h photoperiod. Oat-bran inoculum of Rhizoctonia solani AG-5 isolate 5-103 was prepared as previously described (25). Soils were infested with $R$. solani at a concentration of $0.2 \%(\mathrm{wt} / \mathrm{wt})$ and incubated overnight at $20^{\circ} \mathrm{C}$. Nontreated orchard soil and orchard soil that was pasteurized after completion of three growth-cycles with 'Penawawa' wheat were infested with $R$. solani at the same rate and served as controls. Soils were dispensed in plastic pots ( 3.8 liter volume, $16 \mathrm{~cm}$ diameter). The experiment consisted of two replicate trays per treatment, and from each tray of soil three pots were planted with five 8-weekold 'Gala' seedlings. Pots were arranged in a completely randomized experimental design on the greenhouse bench. Seedlings were grown in the greenhouse for a period of 12 weeks under the conditions described above. At harvest, seedling root systems were washed under a stream of tap water and plant height, shoot weight, and root weight were determined.

Soil mineral analysis. A 100-ml soil subsample was collected from each of the six soil samples for each soil treatment prior to infestation with R.solani AG-5. Soil mineral analysis (P, K, S, and total N) was performed by Soiltest Farm Consultants, Inc. (Moses Lake, WA). Analyses were performed on soils at the completion of wheat cultivation and included WVC-A soils that were not treated, cultivated with 'Penawawa' or 'Hill-81' wheat, or cultivated with 'Penawawa' prior to pasteurization.

Assessment of fungal root colonization. Composition of the fungal community colonizing the roots of 'Gala' apple seedlings was determined. After the washing of root systems, 10 root segments ( 0.5 to $1.0 \mathrm{~cm}$ long) from each seedling were plated on $1.5 \%$ water agar amended with ampicillin $\left(100 \mu \mathrm{g} \mathrm{ml}^{-1}\right)$. Agar plates were incubated at room temperature $\left(20\right.$ to $\left.24^{\circ} \mathrm{C}\right)$, and root segments were examined with a light microscope $(\times 100)$ after 24 and $48 \mathrm{~h}$ for emergence of hyphae characteristic of Rhizoctonia and Pythium spp. The same root segments were examined again at $72 \mathrm{~h}$ and all other sporulating fungi were identified to genus.

Relative tolerance of wheat cultivars to $R$. solani AG-8. Bioassays were conducted to determine the susceptibility of the different wheat cultivars used in this study to the pathogen $R$. solani AG-8. WVC-A orchard soil, or the same orchard soil cultivated to three successive 28-day growth cycles of an individual wheat cultiver as described above, were infested with oat-bran inoculum of $R$. solani AG-8 isolate C- 1 at a rate of $0.2 \%$ (wt/wt). Soil was dispensed in cone-tainers $(21 \mathrm{~cm}$ depth, $3.8 \mathrm{~cm}$ top diameter; Stuewe and Sons, Inc., Corvallis, OR) and three seeds of wheat cvs. Eltan, Hill-81, Lewjain, Madsen, or Penawawa were placed on the soil surface in each cone. Soils previously cultivated with wheat were replanted to the same wheat cultiver. Seed was covered with fine vermiculite to a depth of $1 \mathrm{~cm}$, and thinned to one plant per cell after emergence. Plants were arranged in a completely randomized design with 10 replicates per treatment.

Wheat was harvested after 28 days, and root systems were washed under tap water. For each treatment, 10 root segments $(0.5$ to $1.0 \mathrm{~cm}$ long) were randomly excised from each plant and plated on water agar amended with ampicillin $\left(100 \mu \mathrm{g} \mathrm{ml}^{-1}\right)$ and kanamycin $\left(75 \mu \mathrm{g} \mathrm{ml}^{-1}\right)$. Plates were incubated at room temperature, and root segments were examined using a compound microscope $(\times 100)$ after 24 and $48 \mathrm{~h}$ incubation to determine the presence of $R$. solani. Shoot weight and root weight were determined.

Analysis of the fluorescent pseudomonad community. Soil populations of fluorescent Pseudomonas spp. were determined at 
the completion of wheat cycling in each orchard soil prior to infestation with $R$. solani and included the nontreated and pasteurized soils. Suspensions from each of the six soil samples were prepared by placing $1 \mathrm{~g}$ of soil in $10 \mathrm{ml}$ of sterile water and vortexing for $60 \mathrm{~s}$. Serial dilutions of the soil suspension were plated on King's medium B (KMB) agar amended with ampicillin (100 $\left.\mu \mathrm{g} \mathrm{m}^{-1}\right)$, chloramphenicol $\left(13 \mu \mathrm{g} \mathrm{m}^{-1}\right)$, and cycloheximide $\left(75 \mu \mathrm{g} \mathrm{ml}^{-1}\right)\left(\mathrm{KMB}^{+}\right)(37)$. Fluorescent colonies were counted after 72 -h incubation at $28^{\circ} \mathrm{C}$. For each soil suspension, colonies were randomly selected, transferred to fresh $\mathrm{KMB}^{+}$agar plates, and 10 fluorescent pseudomonads for each soil sample were analyzed by gas chromatography of fatty acid methyl esters (GCFAME) and restriction fragment length polymorphism (RFLP) analysis of the 16s rRNA gene as described below.

The bacterial isolates were subcultured on tripticase soy agar (Becton Dickinson, Co., Sparks, MD) medium and incubated for $24 \mathrm{~h}$ at $24^{\circ} \mathrm{C}$. Isolates were identified by GC-FAME analysis using a Microbial Identification System equipped with an HP5890 Series II gas chromatograph, HP3365 Chem Station, and Aerobe library version 3.9 (MIDI, Inc., Newark, DE) per the manufacturers protocols.

Genetic composition of the fluorescent pseudomonad community from WVC-A orchard soil was described by RFLP analysis of the 16S rRNA gene. Bacteria were cultivated overnight at $24^{\circ} \mathrm{C}$ on nutrient broth yeast extract agar (NBY; 43). Total DNA for use in polymerase chain reaction (PCR) was generated using a modification of the method developed by Raaijmakers et al. (33). Bacteria were pelleted in $0.6 \mathrm{ml}$ micro-centrifuge tubes, suspended in $100 \mu \mathrm{l}$ of lysis buffer $(0.05 \mathrm{M} \mathrm{NaOH}, 0.25 \%$ sodium dodecyl sulfate), and incubated in a water bath at $100^{\circ} \mathrm{C}$ for $15 \mathrm{~min}$. The

TABLE 1. Root infection and growth of 'Gala' apple seedlings in WVC-A, $\mathrm{CV}$, and $\mathrm{WVC}^{\mathrm{SS}}{ }^{\mathrm{x}}$ orchard soils infested with Rhizoctonia solani anastomosis group (AG)-5 after soils had been cultivated to three successive 28-day growth cycles of the indicated wheat cultivar

\begin{tabular}{lccc}
\hline Treatment $^{\mathrm{y}}$ & Root wt $(\mathrm{g})$ & Shoot wt $(\mathrm{g})$ & \% Root infection \\
\hline WVC-A & & & \\
Control & $0.47 \mathrm{a}^{\mathrm{z}}$ & $1.11 \mathrm{a}$ & $18.2 \mathrm{~b}$ \\
Penawawa $95^{\circ} \mathrm{C}$ & $0.93 \mathrm{bc}$ & $1.62 \mathrm{a}$ & $43.6 \mathrm{c}$ \\
Eltan & $0.87 \mathrm{bc}$ & $3.76 \mathrm{~cd}$ & $25.8 \mathrm{~b}$ \\
Hill-81 & $0.58 \mathrm{ab}$ & $2.59 \mathrm{bc}$ & $16.7 \mathrm{~b}$ \\
Lewjain & $1.04 \mathrm{c}$ & $4.79 \mathrm{~d}$ & $3.3 \mathrm{a}$ \\
Madsen & $0.66 \mathrm{ab}$ & $2.42 \mathrm{ab}$ & $18.9 \mathrm{~b}$ \\
Penawawa & $0.94 \mathrm{bc}$ & $4.04 \mathrm{~cd}$ & $1.4 \mathrm{a}$ \\
CV & & & \\
Control & $0.17 \mathrm{a}$ & $0.42 \mathrm{a}$ & $26.7 \mathrm{bc}$ \\
Penawawa $95^{\circ} \mathrm{C}$ & $0.46 \mathrm{ab}$ & $1.73 \mathrm{~b}$ & $48.0 \mathrm{~d}$ \\
Eltan & $0.34 \mathrm{ab}$ & $1.38 \mathrm{~b}$ & $24.4 \mathrm{bc}$ \\
Hill-81 & $0.51 \mathrm{ab}$ & $1.32 \mathrm{~b}$ & $29.3 \mathrm{c}$ \\
Lewjain & $1.02 \mathrm{c}$ & $4.16 \mathrm{~d}$ & $1.3 \mathrm{a}$ \\
Madsen & $0.57 \mathrm{abc}$ & $2.21 \mathrm{bc}$ & $14.0 \mathrm{ab}$ \\
Penawawa & $0.75 \mathrm{bc}$ & $3.08 \mathrm{~cd}$ & $3.3 \mathrm{a}$ \\
WVC-SS & & & \\
Control & $0.56 \mathrm{a}$ & $1.49 \mathrm{a}$ & $22.6 \mathrm{~b}$ \\
Penawawa $95^{\circ} \mathrm{C}$ & $0.87 \mathrm{ab}$ & $2.79 \mathrm{~b}$ & $39.3 \mathrm{c}$ \\
Eltan & $0.68 \mathrm{a}$ & $2.34 \mathrm{ab}$ & $23.3 \mathrm{~b}$ \\
Hill-81 & $0.74 \mathrm{a}$ & $2.53 \mathrm{ab}$ & $21.4 \mathrm{~b}$ \\
Lewjain & $1.23 \mathrm{~b}$ & $3.12 \mathrm{~b}$ & $7.3 \mathrm{a}$ \\
Madsen & $0.59 \mathrm{a}$ & $2.09 \mathrm{ab}$ & $20.7 \mathrm{~b}$ \\
Penawawa & $1.25 \mathrm{~b}$ & $3.40 \mathrm{~b}$ & $10.0 \mathrm{a}$ \\
\hline
\end{tabular}

x WVC-A = Wenatchee Valley College-Auvil Research and Demonstration Orchard, E. Wenatchee, WA; CV = Columbia View Experimental Orchard, Orondo, WA; WVC-SS = Wenatchee Valley College Sunnyslope Orchard, Wenatchee, WA.

${ }^{y}$ After wheat cultivation, all soils including the control were infested with oat-bran inoculum (25) of $R$. solani AG-5 isolate 5-103 at a rate of $0.2 \%$ (wt/wt). Pasteurized soil was cultivated to 'Penawawa' wheat as described in Material and Methods, exposed to steam treatment at $95^{\circ} \mathrm{C}$ for two successive 4-h periods, and cooled prior to addition of pathogen inoculum.

${ }^{z}$ Means in the same column followed by the same letter are not significantly $(P=0.05)$ different based on the Student-Newman-Keuls test. suspensions were vortexed for $30 \mathrm{~s}$, and tubes were returned to the water bath for an additional $15 \mathrm{~min}$. The cell suspensions were centrifuged for $1 \mathrm{~min}$ at $14,000 \mathrm{rpm}$ and the supernatants were transferred to $1.5 \mathrm{ml}$ micro-centrifuge tube. The crude DNA preparations were each diluted with $1.4 \mathrm{ml}$ of sterile distilled water prior to use in PCR.

The primers used in these studies, 8f (5'AGAGTTTGATCCTGGCTCAG3') and 1406r (5'ACGGGCGGTGTGTRC3') are from conserved regions of the $16 \mathrm{~S}$ rRNA gene (2). DNA was amplified in 50- $\mu \mathrm{l}$ volumes containing $1 \times$ PCR buffer, $200 \mu \mathrm{M}$ of each deoxynucleoside triphosphate at a concentration of $200 \mu \mathrm{M}$, $1.5 \mathrm{mM} \mathrm{MgCl}{ }_{2}$, each primer at a concentration of $0.1 \mu \mathrm{M}, 0.1 \mu \mathrm{M}$ each primer, and $2.5 \mathrm{U}$ of Taq polymerase (Gibco BRL, Gaithersburg, MD). Samples were amplified in a DNA GENE AMP 9700 thermal cycler (Perkin-Elmer, Norwalk, CT) at $95^{\circ} \mathrm{C}$ for $3 \mathrm{~min}$ followed by 35 cycles consisting of denaturation $\left(30 \mathrm{~s}\right.$ at $\left.95^{\circ} \mathrm{C}\right)$, annealing $\left(45 \mathrm{~s}\right.$ at $\left.58^{\circ} \mathrm{C}\right)$, and extension $\left(2 \mathrm{~min}\right.$ at $\left.72^{\circ} \mathrm{C}\right)$ with a final extension at $72^{\circ} \mathrm{C}$ for $5 \mathrm{~min}$. Amplified DNA products were verified by electrophoresis of 5 - $\mu$ l aliquots of PCR mixtures through $1.0 \%$ agarose gels in $1 \times \mathrm{TBE}$ buffer and visualization following ethidium bromide treatment.

PCR products $(5 \mu \mathrm{l})$ were digested in a $20-\mu \mathrm{l}$ volume containing $5 \mathrm{U}$ of restriction endonucleases. DNA fragments were digested with the individual restriction endonucleases AluI, DdeI, HinfI, and $R s a \mathrm{I}$, and with the following combinations of restriction endonucleases; HaeIII with HhaI and MspI with RsaI (Gibco BRL). Restriction fragments were separated by electrophoresis through $2 \%$ agarose gels in $1 \times \mathrm{TBE}$ buffer for $3.5 \mathrm{~h}$ at $75 \mathrm{~V}$. Gels were stained with ethidium bromide, and DNA was visualized by UV illumination and photographed. Banding patterns were scored by comparison to 100-bp DNA ladder (Gibco BRL). Each strain was assigned a $16 \mathrm{~S}$ rDNA genotype defined by the composite of restriction patterns obtained (11).

Antagonistic capacity of fluorescent Pseudomonas spp. The capacity of the fluorescent pseudomonad strains, isolated from orchard soils as described above, to inhibit the apple pathogen $R$. solani AG-5 isolate 5-103 and the wheat pathogen $R$. solani AG-8 isolate $\mathrm{C}-1$ was determined in agar plate assays. $R$. solani was grown on one-fifth potato dextrose agar, and a $0.3-\mathrm{cm}$ agar plug was excised from the actively growing margin of the culture and transferred to the center of a 20 -cm-diameter plate containing NBY agar. An individual fluorescent Pseudomonas strain was suspended in $1 \mathrm{ml}$ of sterile deionized water, and an 8 - $\mu$ l aliquot of the bacterial suspension was placed on opposing sides of the fungal inoculum $0.5 \mathrm{~cm}$ from the edge of the petri dish, with two replicates per bacterial isolate. Plates were incubated at $28^{\circ} \mathrm{C}$ for $72 \mathrm{~h}$, and widths of inhibition zones between the margin of the bacterial colony and the advancing mycelial growth of the fungus were measured.

Statistical analyses. Percent root infection data were transformed to arcsine-square root values prior to analysis. Fluorescent pseudomonad soil population data were transformed to $\log _{10}$ values prior to analysis. Data for plant growth and percent root infection were subjected to analysis of variance and means

TABLE 2. Impact of wheat cultivation on mineral content $(\mathrm{mg} / \mathrm{kg})$ of Wenatchee Valley College-Auvil Research and Demonstration Orchard soil

\begin{tabular}{lcccc}
\hline Treatment & $\mathrm{N}$ & $\mathrm{P}$ & $\mathrm{K}$ & $\mathrm{S}$ \\
\hline Control & $19 \mathrm{~b}^{\mathrm{y}}$ & $31 \mathrm{a}$ & $174 \mathrm{a}$ & $7 \mathrm{a}$ \\
Penawawa $95^{\circ} \mathrm{C}^{\mathrm{z}}$ & $5 \mathrm{a}$ & $31 \mathrm{a}$ & $187 \mathrm{a}$ & $6 \mathrm{a}$ \\
Penawawa & $3 \mathrm{a}$ & $34 \mathrm{a}$ & $184 \mathrm{a}$ & $7 \mathrm{a}$ \\
Hill-81 & $3 \mathrm{a}$ & $29 \mathrm{a}$ & $156 \mathrm{a}$ & $7 \mathrm{a}$ \\
\hline
\end{tabular}

${ }^{y}$ Means in the same column followed by the same letter are not significantly $(P=0.05)$ different based on the Student-Newman-Keuls test.

z Pasteurized soil was cultivated to 'Penawawa' wheat as described in Material and Methods, exposed to steam treatment at $95^{\circ} \mathrm{C}$ for two successive 4-h periods, and cooled prior to soil sampling. 
separation using the Student-Newman-Keuls method. Data from in vitro studies on inhibitory activity of fluorescent Pseudomonas spp. toward $R$. solani were not normally distributed and were analyzed by one-way nonparametric Kruskal-Wallis test followed by pairwise comparison of means using the Student-NewmanKeuls method. Statistical analyses were conducted using SigmaStat, version 2.0 (SPSS, San Rafael, CA). All experiments were conducted twice. Similar results were observed in both experiments except where noted in the text. Data from the initial experiment are presented as in this trial certain disparities in apple growth were observed for a specific wheat cultivar treatment among the different orchard soils.

\section{RESULTS}

The percentage of roots infected with Rhizoctonia spp. for apple grown in orchard soils cultivated to either 'Lewjain' or 'Penawawa' prior to infestation with $R$. solani was significantly $(P=0.05)$ reduced relative to that observed for the nontreated infested control regardless of soil source (Table 1). Growth of apple seedlings in these same soils was always enhanced relative to the nontreated infested control. Conversely, prior cultivation of orchard soils with 'Hill-81' or 'Madsen' had no significant impact on apple root infection by $R$. solani, and root biomass of seedlings grown in these soils was similar to the nontreated control. Shoot biomass of apple seedlings grown in these soils occasionally was greater relative to the control, but never attained that observed for seedlings grown in 'Lewjain'- or 'Penawawa'-cultivated soils. 'Eltan'cultivated soils were not suppressive to root rot caused by the introduced isolate of $R$. solani, and typically, growth of apple in these soils was not enhanced. A notable exception was observed during the initial experiment conducted in WVC-A orchard soil cultivated to 'Eltan' in which root and shoot biomass were higher relative to the nontreated infested control (Table 1). Pasteurization prior to infestation with $R$. solani AG-5 isolate 5-103 eliminated the Rhizoctonia-suppressive potential of 'Penawawa'-cultivated orchard soil, and root infection was significantly greater than the nontreated infested control in all orchard soils examined.

Wheat cultivation of orchard soils had significant impacts on soil fertility. At the end of the three wheat cycles, soil nitrogen content was significantly $(P<0.0001)$ reduced in 'Penawawa'and 'Hill-81'-cultivated soils relative to the nontreated control soil (Table 2). There was no significant difference in total nitrogen content between soils cultivated with 'Penawawa' or 'Hill-81' wheat, and pasteurization of 'Penawawa'-cultivated soil had no impact on nitrogen content. All WVC-A soils tested were equivalent in terms of $\mathrm{P}, \mathrm{K}$, and $\mathrm{S}$ content.

Although pasteurized 'Penawawa'-cultivated orchard soils were not suppressive to $R$. solani, the average biomass of seedlings

TABLE 3. Relative recovery (\%) of Fusarium spp. from roots of apple grown in wheat cultivated orchard soils

\begin{tabular}{lccc}
\hline Treatment & WVC-A & CV & WVC-SS \\
\hline Control & $1 \mathrm{a}^{\mathrm{y}}$ & $14 \mathrm{~b}$ & $9 \mathrm{a}$ \\
Penawawa $95^{\circ} \mathrm{C}^{\mathrm{z}}$ & $0 \mathrm{a}$ & $23 \mathrm{bc}$ & $7 \mathrm{a}$ \\
Eltan & $8 \mathrm{ab}$ & $22 \mathrm{bc}$ & $24 \mathrm{~b}$ \\
Hill-81 & $11 \mathrm{ab}$ & $3 \mathrm{a}$ & $22 \mathrm{~b}$ \\
Lewjain & $23 \mathrm{c}$ & $43 \mathrm{~d}$ & $38 \mathrm{c}$ \\
Madsen & $15 \mathrm{bc}$ & $17 \mathrm{~b}$ & $24 \mathrm{~b}$ \\
Penawawa & $26 \mathrm{c}$ & $32 \mathrm{c}$ & $34 \mathrm{bc}$ \\
\hline
\end{tabular}

x WVC-A = Wenatchee Valley College-Auvil Research and Demonstration Orchard, E. Wenatchee, WA; CV = Columbia View Research and Demonstration Orchard, Orondo, WA; WVC-SS = Wenatchee Valley College Sunnyslope Orchard, Wenatchee, WA.

y Means in the same column followed by the same letter are not significantly $(P=0.05)$ different based on the Student-Newman-Keuls test.

z Pasteurized soil was cultivated to 'Penawawa' wheat as described in Material and Methods, exposed to steam treatment at $95^{\circ} \mathrm{C}$ for two successive 4-h periods and cooled prior to soil sampling. grown in these soils commonly was intermediate between that obtained in the nontreated infested control and that observed in the 'Lewjain'- or 'Penawawa'-cultivated soils. Soil pasteurization effectively eliminated or significantly suppressed apple root infection by the pathogen complex resident in these soils. For example, Pythium root infection was $41 \%$ for seedlings grown in nontreated WVC-SS orchard soil but less than $2 \%$ for seedlings grown in pasteurized soil from the same site. In CV soil, Cylindrocarpon root infection for seedlings grown in nontreated soil was $45 \%$, but this fungus was recovered from only $12 \%$ of apple roots grown in pasteurized soil.

Recovery of Fusarium spp. from roots of apple seedlings frequently was higher from the roots of apple seedlings grown in wheat-cultivated orchard soils than the corresponding nontreated orchard soil (Table 3). Relative recovery of Fusarium spp. from apple grown in 'Lewjain' - or 'Penawawa'-cultivated orchard soils commonly was higher than from seedlings grown in the corresponding soil cultivated with 'Eltan', 'Hill-81', or 'Madsen'. With the exception of pasteurized soils, Trichoderma spp. were recovered from less than $2 \%$ of apple root segments regardless of orchard soil or treatment. Trichoderma spp. were isolated from 4 and 13\% of root segments from apple grown in pasteurized CV and WVCSS orchard soils, respectively.

All wheat cultivars exhibited a similar level of susceptibility when planted in soil artificially infested with $R$. solani AG-8 isolate C-1 (Table 4). Root infection rates were not significantly different among wheat cultivars and ranged from 22 to $35 \%$. However, differential root infection was observed when the same isolate of $R$. solani was introduced into soil cultivated to three successive cycles of wheat and replanted to the same wheat cultivar. Although percent root infection was lower for all wheat cultivars relative to that observed when soils were infested at the initial planting, recovery of $R$. solani from roots of 'Lewjain' or 'Penawawa' was substantially lower than from roots of 'Eltan', 'Hill-81', or 'Madsen'. However, the lower rate of root infection on 'Lewjain' and 'Penawawa' did not result in a corresponding increase in plant biomass relative to the other three wheat cultivars, and biomass of wheat seedlings was significantly $(P<0.0001)$ lower when grown in $R$. solani infested soil, in comparison to noninfested soil, regardless of wheat cultivar (data not shown).

Cultivation of orchard replant soils with wheat significantly enhanced fluorescent Pseudomonas spp. populations (Table 5). No significant differences in total populations were observed among soils cultivated to different wheat cultivars. However, the composition of the fluorescent pseudomonad population recovered from orchard soils was modified in a wheat cultivar-specific manner as determined by GC-FAME analysis and distribution of $16 \mathrm{~S}$ rDNA genotypes. $P$. putida biotype (btp) A commonly represented a greater proportion of the fluorescent pseudomonad population recovered from orchard soil cultivated with wheat relative to the corresponding nontreated orchard soil (Table 6). In addition, soils cultivated with 'Lewjain' or 'Penawawa' possessed a correspondingly higher proportion of $P$. putida btp A isolates than did soils cultivated to 'Eltan', 'Hill-81', or 'Madsen' wheat.

TABLE 4. Relative root infection (\%) of wheat sown in Wenatchee Valley College-Auvil Research and Demonstration Orchard soil infested with Rhizoctonia solani anastomosis group (AG)-8 strain C-1

\begin{tabular}{lcc}
\hline & \multicolumn{2}{c}{ Time of soil infestation $^{\mathrm{z}}$} \\
\cline { 2 - 3 } Wheat cultivar & Initial wheat cycle & After 3rd wheat cycle \\
\hline Eltan & $24 \mathrm{a}$ & $14 \mathrm{a}$ \\
Hill-81 & $35 \mathrm{a}$ & $13 \mathrm{a}$ \\
Lewjain & $32 \mathrm{a}$ & $5 \mathrm{~b}$ \\
Madsen & $22 \mathrm{a}$ & $14 \mathrm{a}$ \\
Penawawa & $26 \mathrm{a}$ & $6 \mathrm{~b}$ \\
\hline
\end{tabular}

${ }^{\mathrm{z}}$ Means in the same column followed by the same letter are not significantly $(P=0.05)$ different based on the Student-Newman-Keuls test. 
Genotype 1 dominated the fluorescent pseudomonad population recovered from WVC-A orchard soil regardless of treatment (Table 7). Isolates defined as genotype 2, 6, 9, 11, 13, and 38 represent strains that possess antagonistic activity toward $R$. solani AG-5 (11). These genotypes comprised a significantly $(P<$ 0.05 ) greater proportion of the population (approximately $50 \%$ ) recovered from 'Penawawa'- or 'Lewjain'-cultivated soil, than that recovered from nontreated soil or soil cultivated to 'Eltan', 'Hill-81', or 'Madsen' wheat where the same genotypes did not represent greater than $25 \%$ of the population.

The proportion of the resident fluorescent pseudomonad community with the capacity to inhibit in vitro growth of $R$. solani AG-5 was altered by growing wheat in orchard replant soils. The

TABLE 5. Soil populations (log CFU per gram of soil) of fluorescent Pseudomonas spp. in replant orchard soils and in the respective soils at completion of three 28-day growth cycles of the indicated wheat variety

\begin{tabular}{llcc}
\hline Treatment $^{\mathrm{x}}$ & WVC-A $^{\mathrm{y}}$ & CV & WVC-SS \\
\hline Control & $6.02 \mathrm{~b}^{\mathrm{z}}$ & $5.98 \mathrm{~b}$ & $5.86 \mathrm{~b}$ \\
Penewawa $95^{\circ} \mathrm{C}$ & $4.25 \mathrm{a}$ & $3.36 \mathrm{a}$ & $3.11 \mathrm{a}$ \\
Eltan & $7.25 \mathrm{c}$ & $7.38 \mathrm{c}$ & $7.02 \mathrm{c}$ \\
Hill-81 & $6.99 \mathrm{c}$ & $7.42 \mathrm{c}$ & $6.86 \mathrm{c}$ \\
Lewjain & $7.36 \mathrm{c}$ & $7.31 \mathrm{c}$ & $6.65 \mathrm{c}$ \\
Madsen & $7.08 \mathrm{c}$ & $7.08 \mathrm{c}$ & $6.64 \mathrm{c}$ \\
Penawawa & $7.14 \mathrm{c}$ & $7.57 \mathrm{c}$ & $7.04 \mathrm{c}$ \\
\hline
\end{tabular}

${ }^{\mathrm{x}}$ All soils were sampled prior to infestation with Rhizoctonia solani anastomosis group (AG)-5. Control soil consisted of nontreated orchard soil incubated in the greenhouse under the same conditions and for the same duration as wheat cultivated soils. Pasteurized soil was cultivated to 'Penawawa' wheat as described in Material and Methods, exposed to steam treatment at $95^{\circ} \mathrm{C}$ for two successive 4-h periods and cooled prior to soil sampling.

${ }^{y}$ WVC-A = Wenatchee Valley College-Auvil Research and Demonstration Orchard, E. Wenatchee, WA; CV = Columbia View Experimental Orchard, Orondo, WA; WVC-SS = Wenatchee Valley College Sunnyslope Orchard, Wenatchee, WA.

${ }^{\mathrm{z}}$ Means in the same column followed by the same letter are not significantly $(P=0.05)$ different based on the Student-Newman-Keuls test. majority of fluorescent Pseudomonas spp. isolates recovered from nontreated orchard soils lacked the ability to suppress fungal growth in vitro, and the few isolates that did exhibit the capacity to inhibit growth of $R$. solani strain 5-103 induced minor $(<1 \mathrm{~mm})$ inhibition zones. The population resident in the same orchard soils cultivated to 'Eltan', 'Madsen', or 'Hill-81' usually did not possess antagonistic activity substantially different from that obtained from the corresponding nontreated replant orchard soil (Table 8). The fluorescent pseudomonad population from orchard soils cultivated with 'Penawawa' consistently exhibited a level of in vitro antagonism toward $R$. solani AG-5 that was significantly greater than the population recovered from nontreated soils. The fluorescent Pseudomonas spp. population from 'Lewjain'-cultivated soil always demonstrated a numerically higher, though in experiment 1 the population from $\mathrm{CV}$ orchard soil was not statistically different, level of antagonism in vitro toward the pathogen. Differences among soil treatments in antagonistic capacity of the fluorescent pseudomonad population toward $R$. solani AG-8 isolate $\mathrm{C}-1$ typically were similar to those observed for $R$. solani AG-5 (Table 8).

\section{DISCUSSION}

Induction of soil suppressiveness to $R$. solani previously was demonstrated in response to successive plantings of alfalfa, radish, or sugarbeet, and disease suppression was shown to function through an increase in the population of chitinolytic fungi (13), including $T$. harzianum (24), rather than an increase in the antagnistic potential of the resident soil microflora. In a naturally occurring soil suppressive to Rhizoctonia root rot of apple, a decrease in soil suppressiveness toward $R$. solani AG-5 with increasing orchard age was associated with a reduction in recovery of Trichoderma spp. from the roots of apple and a specific conversion in the fluorescent pseudomonad community (28). This transformation was characterized by a change in the dominant fluorescent pseudomonad from P. putida to P. fluorescens bv. III.

TABLE 6. Composition of the fluorescent Pseudomonas spp. population recovered from replant orchard soils and the respective soils at the completion of three 28-day growth cycles of the indicated wheat cultivar ${ }^{\mathrm{x}}$

\begin{tabular}{|c|c|c|c|c|c|c|c|c|}
\hline Treatment & $\begin{array}{c}\text { Pseudomonas } \\
\text { putida } \text { btp A }\end{array}$ & P. putida btp B & $\begin{array}{c}\text { P. fluorescens } \\
\text { bv. I }\end{array}$ & $\begin{array}{l}\text { P. fluorescens } \\
\text { bv. III }\end{array}$ & $\begin{array}{l}\text { P. fluorescens } \\
\text { bv. IV }\end{array}$ & $\begin{array}{l}\text { P. fluorescens } \\
\text { bv V }\end{array}$ & P. syringae & P. aureofaciens \\
\hline \multicolumn{9}{|l|}{ WVC-A ${ }^{y}$} \\
\hline Control & $0 \mathrm{a}$ & $6 \mathrm{a}$ & $0 \mathrm{a}$ & $52 \mathrm{~b}$ & $6 \mathrm{a}$ & $0 \mathrm{a}$ & $24 \mathrm{~b}$ & $12 \mathrm{a}$ \\
\hline Penawawa $95^{\circ} \mathrm{C}^{\mathrm{z}}$ & $24 \mathrm{~b}$ & $23 \mathrm{~b}$ & $4 \mathrm{a}$ & $23 \mathrm{a}$ & $0 \mathrm{a}$ & $7 \mathrm{a}$ & $15 \mathrm{ab}$ & $4 \mathrm{a}$ \\
\hline Eltan & $26 \mathrm{~b}$ & $8 \mathrm{a}$ & $3 \mathrm{a}$ & $21 \mathrm{a}$ & $11 \mathrm{a}$ & $2 \mathrm{a}$ & $24 \mathrm{~b}$ & $5 \mathrm{a}$ \\
\hline Hill-81 & $18 \mathrm{~b}$ & $17 \mathrm{ab}$ & $0 \mathrm{a}$ & $13 \mathrm{a}$ & $3 a$ & $0 \mathrm{a}$ & $31 \mathrm{~b}$ & $3 \mathrm{a}$ \\
\hline Lewjain & $63 \mathrm{c}$ & $8 \mathrm{a}$ & $0 \mathrm{a}$ & $13 \mathrm{a}$ & $0 \mathrm{a}$ & $0 \mathrm{a}$ & $5 \mathrm{a}$ & $12 \mathrm{a}$ \\
\hline Madsen & $17 \mathrm{~b}$ & $7 \mathrm{a}$ & $0 \mathrm{a}$ & $42 \mathrm{~b}$ & $12 \mathrm{a}$ & $5 \mathrm{a}$ & $2 \mathrm{a}$ & $14 \mathrm{a}$ \\
\hline Penawawa & $39 \mathrm{~b}$ & $24 \mathrm{~b}$ & $0 \mathrm{a}$ & $14 \mathrm{a}$ & $5 \mathrm{a}$ & $0 \mathrm{a}$ & $6 \mathrm{a}$ & $13 \mathrm{a}$ \\
\hline \multicolumn{9}{|l|}{$\mathrm{CV}$} \\
\hline Control & $17 \mathrm{a}$ & $5 \mathrm{a}$ & $0 \mathrm{a}$ & $3 \mathrm{a}$ & $0 \mathrm{a}$ & $0 \mathrm{a}$ & $80 \mathrm{c}$ & $0 \mathrm{a}$ \\
\hline Penawawa $95^{\circ} \mathrm{C}$ & $5 \mathrm{a}$ & $3 a$ & $3 a$ & $26 \mathrm{ab}$ & $0 \mathrm{a}$ & $8 \mathrm{a}$ & $51 \mathrm{~b}$ & $5 \mathrm{a}$ \\
\hline Eltan & $17 \mathrm{a}$ & $10 \mathrm{a}$ & $0 \mathrm{a}$ & $30 \mathrm{~b}$ & $8 \mathrm{a}$ & $3 a$ & $28 \mathrm{ab}$ & $5 \mathrm{a}$ \\
\hline Hill-81 & $22 \mathrm{a}$ & $2 \mathrm{a}$ & $0 \mathrm{a}$ & $43 \mathrm{~b}$ & $5 \mathrm{a}$ & $0 \mathrm{a}$ & $3 \mathrm{a}$ & $15 \mathrm{a}$ \\
\hline Lewjain & $76 \mathrm{~b}$ & $11 \mathrm{a}$ & $0 \mathrm{a}$ & $0 \mathrm{a}$ & $3 a$ & $0 \mathrm{a}$ & $5 \mathrm{a}$ & $5 \mathrm{a}$ \\
\hline Madsen & $26 \mathrm{a}$ & $0 \mathrm{a}$ & $0 \mathrm{a}$ & $12 \mathrm{a}$ & $7 \mathrm{a}$ & $3 a$ & $44 \mathrm{~b}$ & $3 a$ \\
\hline Penawawa & $59 \mathrm{~b}$ & $0 \mathrm{a}$ & $0 \mathrm{a}$ & $2 \mathrm{a}$ & $2 \mathrm{a}$ & $2 \mathrm{a}$ & $19 \mathrm{a}$ & $5 \mathrm{a}$ \\
\hline \multicolumn{9}{|l|}{ WVC-SS } \\
\hline Control & $0 \mathrm{a}$ & $0 \mathrm{a}$ & $2 \mathrm{a}$ & $2 \mathrm{a}$ & $0 \mathrm{a}$ & $2 \mathrm{a}$ & $89 \mathrm{c}$ & $0 \mathrm{a}$ \\
\hline Penawawa $95^{\circ} \mathrm{C}$ & $0 \mathrm{a}$ & $3 \mathrm{a}$ & $6 a$ & $3 \mathrm{a}$ & $20 \mathrm{~b}$ & $2 \mathrm{a}$ & $54 \mathrm{~b}$ & $11 \mathrm{a}$ \\
\hline Eltan & $36 \mathrm{~b}$ & $10 \mathrm{a}$ & $0 \mathrm{a}$ & $2 \mathrm{a}$ & $0 \mathrm{a}$ & $2 \mathrm{a}$ & $51 \mathrm{~b}$ & $0 \mathrm{a}$ \\
\hline Hill-81 & $27 \mathrm{~b}$ & $13 \mathrm{a}$ & $0 \mathrm{a}$ & $0 \mathrm{a}$ & $0 \mathrm{a}$ & $5 \mathrm{a}$ & $55 \mathrm{~b}$ & $0 \mathrm{a}$ \\
\hline Lewjain & $66 \mathrm{c}$ & $3 a$ & $0 \mathrm{a}$ & $3 a$ & $0 \mathrm{a}$ & $2 \mathrm{a}$ & $18 \mathrm{a}$ & $0 \mathrm{a}$ \\
\hline Madsen & $37 \mathrm{~b}$ & $0 \mathrm{a}$ & $0 \mathrm{a}$ & $20 \mathrm{~b}$ & $0 \mathrm{a}$ & $13 \mathrm{a}$ & $30 \mathrm{ab}$ & $0 \mathrm{a}$ \\
\hline Penawawa & $74 \mathrm{c}$ & $10 \mathrm{a}$ & $0 \mathrm{a}$ & $0 \mathrm{a}$ & $0 \mathrm{a}$ & 5 a & $11 \mathrm{a}$ & $0 \mathrm{a}$ \\
\hline
\end{tabular}

$x$ Values represent the percentage of the total number of fluorescent pseudomonads examined for a given soil. Values in a column followed by the same letter are not significantly $(P=0.05)$ different based on the Student-Newman-Keuls test.

${ }^{y}$ WVC-A = Wenatchee Valley College Auvil Research and Demonstration Orchard, CV = Columbia View Experimental Orchard, and WVC-SS $=$ Wenatchee Valley College Sunnyslope Demonstration Orchard, WA.

${ }^{z}$ Pasteurized soil, which was cultivated to 'Penawawa' wheat as described in Material and Methods, exposed to steam treatment at $95^{\circ} \mathrm{C}$ for two successive 4-h periods, and cooled prior to soil sampling. 
When the same soil was cultivated to wheat prior to planting apple, infection of apple roots by the resident population of $R$. solani was reduced and associated with an increase in the relative proportion of $P$. putida in the fluorescent pseudomonad population recovered from the apple rhizosphere (30).

In the current study, soils planted to different wheat cultivars were differentially suppressive to Rhizoctonia root rot of apple caused by an introduced isolate of $R$. solani AG-5. Soils planted with wheat cultivars that induced disease suppressiveness possessed a fluorescent pseudomonad population that exhibited a greater degree of in vitro inhibition toward $R$. solani AG-5 than did the population from the nontreated orchard soil or soils cultivated to wheat cultivars that did not induce disease suppressiveness. However, no association between the induction of disease suppressiveness and the relative recovery of Trichoderma spp. from the roots of apple seedlings grown in these soils was observed. The apparent difference in the functional microbial community in disease suppression between this and previous studies may reside in soil chemical attributes. Soils used in this study all possessed a soil $\mathrm{pH}$ near neutrality $(\mathrm{pH}=6.5$ to 7.1). Chet and Baker (5) found that the role of $T$. harzianum in soil suppressiveness toward $R$. solani induced through crop monoculture was limited to acidic soils. Pasteurization of soils planted to a wheat cultivar that induced disease suppression eliminated soil suppressiveness. These findings indicate that the induced disease suppressiveness is biological in nature and suggests that transformation of the resident fluores-

TABLE 7. Genetic composition of fluorescent pseudomonad populations recovered from Wenatchee Valley College Auvil Research and Demonstration Orchard replant soil and cultivated with the indicated wheat variety

\begin{tabular}{lcrrrrr}
\hline 16S rDNA & \multicolumn{5}{c}{ Treatment } \\
\cline { 2 - 7 } Genotypey $^{n}$ & Control & Eltan & Hill-81 & Lewjain & Madsen & Penawawa \\
\hline 1 & $47^{z}$ & 42 & 44 & 25 & 45 & 29 \\
2 & 0 & 3 & 3 & 9 & 5 & 15 \\
4 & 0 & 0 & 0 & 0 & 0 & 1 \\
6 & 0 & 0 & 1 & 0 & 0 & 0 \\
9 & 0 & 0 & 1 & 0 & 0 & 0 \\
10 & 0 & 2 & 1 & 1 & 0 & 0 \\
11 & 0 & 2 & 6 & 5 & 2 & 6 \\
13 & 6 & 3 & 1 & 4 & 7 & 4 \\
19 & 0 & 0 & 0 & 0 & 0 & 1 \\
33 & 1 & 2 & 0 & 0 & 0 & 0 \\
35 & 2 & 6 & 1 & 5 & 0 & 0 \\
38 & 4 & 0 & 2 & 11 & 1 & 4 \\
\hline
\end{tabular}

y Genotype previously defined (11) by a composite of the restriction fragment length polymorphism patterns obtained with seven restriction endonucleases.

${ }^{\mathrm{z}}$ Values are the total number of isolates. For each treatment, 10 isolates were analyzed for the population recovered from each of six pots. cent pseudomonad population, in part, contributed to the wheat cultivar-specific induction of a soil suppressive to $R$. solani.

Fusarium spp. have a functional role in several disease suppressive soils $(1,19,20,34)$. In this study, recovery of Fusarium spp. from apple roots commonly was enhanced in wheat cultivated soils. Although relative recovery sometimes varied in the same wheat cultivar-specific manner observed for the fluorescent pseudomonad population, among isolates examined to date, the relative capacity of Fusarium isolates to enhance growth of apple in the presence of $R$. solani was similar irrespective of the wheat cultivar that preceded apple (M. Mazzola and Y.-H. Gu, unpublished data). Thus, the functional role of these fungi in the observed suppression of $R$. solani AG-5 requires further examination.

Disease suppressive soils have been documented for numerous plant/pathogen systems, and the resident soil microbial community contributes significantly to the suppression of disease development (29). Managing the potential of resident soil microbial antagonists would appear to have promise as a means to control soilborne diseases where the functional components of the microbial community are identified. Manipulation of these communities could be accomplished via various cultural practices including the use of amendments or cropping sequences to foster the selective stimulation of the appropriate community. The generation of disease-suppressive soils has been observed in response to continuous crop monoculture $(8,36)$. However, the role of plant genotype in the phenomenon has received scant attention.

Previous studies have suggested a role for plant genotype in mediating disease control through the activity of biocontrol rhizobacteria $(17,23,39)$, including certain fluorescent Pseudomonas spp. (7). Similarly, as the suppressive nature of certain soils function through the activity of various saprophytic elements of the soil microbial community, including Pseudomonas and Fusarium spp., it seems plausible that the induction of soil suppressiveness would vary in a plant species- or cultivar-specific manner. Larkin et al. (19) documented the development of a soil suppressive to Fusarium wilt of watermelon after repeated cultivation of the host plant. However, soil suppressiveness was induced by only a limited number of watermelon cultivars that are resistant to the pathogen $F$. oxysporum f. sp. niveum. The capacity of a cultivar to induce soil suppressiveness was associated with increased populations of nonpathogenic Fusarium spp.

There were no apparent differences in tolerance or susceptibility to $R$. solani AG- 8 among the wheat cultivars used in this study. Differential disease development in wheat was only observed when three wheat growth-cycles had preceded introduction of the pathogen. Likewise, additional assays were employed which utilized one plant species to modify the soil microbial community and a different plant species with which to assess the relative disease suppressive capacity of the resulting soil micro-

TABLE 8. Suppression of in vitro growth of Rhizoctonia solani anastomosis group (AG)-5 and AG-8, expressed as mean width of inhibition zone (mm), by fluorescent Pseudomonas spp. recovered from orchard replant soils after cultivation with the respective wheat cultivars

\begin{tabular}{|c|c|c|c|c|c|c|}
\hline \multirow[b]{2}{*}{ Treatment } & \multicolumn{2}{|c|}{ WVC-A ${ }^{x}$} & \multicolumn{2}{|c|}{$\mathrm{CV}$} & \multicolumn{2}{|c|}{ WVC-SS } \\
\hline & AG-5 & AG-8 & AG-5 & AG-8 & AG-5 & AG-8 \\
\hline Control & $0.71 \mathrm{a}^{\mathrm{y}}$ & $0.25 \mathrm{a}$ & $0.33 \mathrm{a}$ & $0.20 \mathrm{a}$ & $0.06 \mathrm{a}$ & $0.10 \mathrm{a}$ \\
\hline Penawawa $95^{\circ} \mathrm{C}^{\mathrm{z}}$ & $0.63 \mathrm{a}$ & $0.43 \mathrm{a}$ & $0.50 \mathrm{a}$ & $0.35 \mathrm{a}$ & $0.40 \mathrm{a}$ & $0.09 \mathrm{a}$ \\
\hline Hill-81 & $1.30 \mathrm{ab}$ & $0.85 \mathrm{ab}$ & $0.34 \mathrm{a}$ & $0.65 \mathrm{a}$ & $0.43 \mathrm{a}$ & $0.28 \mathrm{a}$ \\
\hline Lewjain & $2.15 b c$ & $3.45 \mathrm{c}$ & $0.74 \mathrm{ab}$ & $1.52 \mathrm{ab}$ & $2.23 \mathrm{c}$ & $1.95 \mathrm{~b}$ \\
\hline Madsen & $0.80 \mathrm{a}$ & $0.54 \mathrm{a}$ & $0.37 \mathrm{a}$ & $1.85 \mathrm{~b}$ & $0.25 \mathrm{a}$ & $0.34 \mathrm{a}$ \\
\hline
\end{tabular}

${ }^{x}$ WVC-A = Wenatchee Valley College-Auvil Research and Demonstration Orchard, E. Wenatchee, WA; CV = Columbia View Research and Demonstration Orchard, Orondo, WA; WVC-SS = Wenatchee Valley College Sunnyslope Orchard, Wenatchee, WA.

y Values are based on an assessment of 60 strains for each treatment recovered after wheat cultivation of soils as described in Materials and Methods. Means in the same column followed by the same letter are not significantly $(P=0.05)$ different based on the Student-Newman-Keuls test.

${ }^{z}$ Pasteurized soil was cultivated to 'Penawawa' wheat as described in Materials and Methods, exposed to steam treatment at $95^{\circ} \mathrm{C}$ for two successive 4-h periods, and cooled prior to soil sampling. 
flora. These plant assays utilized a single cultivar of apple ('Gala'). Taken simultaneously, these data restrict the role of host resistance as a possible explanation for the differential development of disease suppression observed in response to the different wheat cultivars.

The impact of plant species on phenotypic and genetic diversity of the fluorescent pseudomonad community resident to soils has been reported previously $(21,22)$. In our study, wheat cultivars that induced suppressiveness selected for specific species or genotypes of fluorescent pseudomonads that possessed antagonistic activity toward $R$. solani. Fluorescent pseudomonad genotypes 2 and 11 were not detected in WVC-A apple orchard soil prior to planting with wheat, but were recovered from all wheat cultivated soils regardless of the wheat cultivar employed. Isolates representing genotypes that demonstrated in vitro antagonism toward $R$. solani, such as genotypes 2 and 38, were more prevalent in soil cultivated with 'Lewjain' or 'Penawawa' than soil cultivated with 'Eltan', 'Hill-81', or 'Madsen'. Although identification of certain bacterial groups, including the fluorescent Pseudomonas spp., to the species level by GC-FAME is not invariably definitive $(4,11)$, the biochemical analyses demonstrate that similar changes in this community were induced in multiple soils by the same wheat genotype. The fact that a similar response in terms of disease suppression was also observed across multiple soils suggests that host genotype has a significant influence on composition of indigenous saprophytic microbial communities and perhaps to a greater extent than previously postulated.

The host factors responsible for the differential specificity among wheat cultivars in selection of fluorescent Pseudomonas spp. genotypes are not known, though it would seem likely that these differences are driven by qualitative or quantitative variation in substrates released into the rhizosphere. Root biomass production by the wheat cultivars used in this study varied significantly, but not in a manner consistent with the observed disease suppression (Y.-H. Gu and M. Mazzola, unpublished data). This would suggest that qualitative rather than quantitative attributes of the wheat root exudates contributed to the observed genotype specificity.

Studies with specific rhizobacteria also imply a significant role for root exudate composition in determining the efficacy of biological controls. Differential biological disease control has been attributed to the capacity of a cultivar to support populations of the biological agent. However, in other systems cultivar specificity was not related to rhizosphere colonization by the biocontrol strain (23). Differential disease control obtained on different plant cultivars may be associated with differences in expression of genes involved in disease suppression, such as the production of antibiotics or siderophores. Phenazine and pyoluteorin production in the rhizosphere have been shown to differ in response to plant species $(9,18)$, and more recently, differences in expression of the 2,4-diacetylphloroglucinol biosynthesis gene phlA in P. fluorescens strain CHA0 were observed in association with cultivars of maize (32).

The impact of host genotype on composition of the resident soil microflora has received minimal prior study. Our results and those of other investigators $(7,17,19,23,32,39)$ indicate an important role for host genotype in determining the efficacy of resident and introduced microorganisms for the control of soilborne diseases. These studies provide further evidence that genetic variation within the host has the potential to be employed to enhance the interactions with plant-beneficial microorganisms, including those beyond the more commonly studied associations such as mycorrhizae or rhizobia/plant interactions.

\section{ACKNOWLEDGMENTS}

This material is based upon work supported by the USDA National Research Initiative Competitive Grants Program under agreement 200135319-09922.

\section{LITERATURE CITED}

1. Alabouvette, C., Schippers, B., Lemanceau, P., and Bakker, P. A. H. M. 1998. Biological control of Fusarium wilts. Pages 15-36 in: PlantMicrobe Interactions and Biological Control. G. J. Boland and L. D. Kuykendall, eds. Marcel Dekker, Inc., New York.

2. Amann, R. I., Ludwig, W., and Schleifer, K. H. 1995. Phylogenetic identification and in situ detection of individual microbial cells without cultivation. Microbiol. Rev. 59:143-169.

3. Broadbent, P., and Baker, K. F. 1974. Behavior of Phytophthora cinnamomi in soils suppressive and conducive to root rot. Aust. J. Agric. Res. 25:121-137.

4. Brown, B. J., and Leff, L. G. 1996. Comparison of fatty acid methyl ester analysis with the use of API 20E and NFT strips for identification of aquatic bacteria. Appl. Environ. Microbiol. 62:2183-2185.

5. Chet, I., and Baker, R. 1980. Induction of suppressiveness to Rhizoctonia solani in soil. Phytopathology 70:994-998.

6. Cook, R. J., and Rovira, A. D. 1976. The role of bacteria in the biological control of Gaeumannomyces graminis by suppressive soils. Soil Biol. Biochem. 8:267-273.

7. Diab El-Arab, H. G., and Sikora, R. A. 2001. The influence of plant genotype on the antagonistic activity of Pseudomonas fluorescens 2-79 to take-all and changes in the composition of the rhizosphere specific microbial communities on wheat. (Abstr.) Phytopathology 91(suppl.):S23.

8. Gair, R., Mathias, P. L., and Harvey, P. N. 1969. Studies on the cereal nematode populations and cereal yields under continuous or intensive culture. Ann. Appl. Biol. 63:503-512.

9. Georgakopoulos, D. G., Hendson, M., Panopoulos, N. J., and Schroth, M. N. 1994. Analysis of expression of a phenazine biosynthesis locus of Pseudomonas aureofaciens PGS12 on seeds with a mutant carrying a phenazine biosynthesis locus-ice nucleation reporter gene fusion. Appl. Environ. Microbiol. 60:4573-4579.

10. Gu, Y.-H., and Mazzola, M. 2001. Impact of carbon starvation on stress resistance, survival in soil habitats and biocontrol ability of Pseudomonas putida strain 2C8. Soil Biol. Biochem. 33:1155-1162.

11. Gu, Y.-H., and Mazzola, M. 2001. Influence of wheat cultivation on genetic composition of fluorescent pseudomonad populations from apple replant soils. (Abstr.) Phytopathology 91(suppl.):S33.

12. Hancock, J. G. 1977. Factors affecting soil populations of Pythium ultimum in the San Joaquin Valley of California. Hilgardia 45:107-122.

13. Henis, Y., Ghaffar, A., and Baker, R. 1979. Factors affecting suppressiveness to Rhizoctonia solani in soil. Phytopathology 69:1164-1169.

14. Huber, D. M. 1989. The role of nutrition in the take-all disease of wheat and other small grains. Pages 46-74 in: Soilborne Plant Pathogens: Management of Diseases with Macro- and Microelements. A. W. Englehard, ed. The American Phytopathological Society, St. Paul, MN.

15. Huber, D. M., and Schneider, R. W. 1982. The description and occurrence of suppressive soils. Pages 1-7 in: Suppressive Soils and Plant Diseases. R. W. Schneider, ed. The American Phytopathological Society, St. Paul, MN.

16. Kerry, B. R. 1988. Fungal parasites of cyst nematodes. Agric. Ecosyst. Environ. 24:293-305.

17. King, E. B., and Parke, J. L. 1993. Biocontrol of aphanomyces root rot and pythium damping-off by Pseudomonas cepacia AMMD on four pea cultivars. Plant Dis. 77:1185-1188.

18. Kraus, J., and Loper, J. E. 1995. Characterization of a genomic region required for production of the antibiotic pyoluteorin by the biological control agent Pseudomonas fluorescens Pf-5. Appl. Environ. Microbiol. 61:849-854.

19. Larkin, R. P., Hopkins, D. L., and Martin, F. N. 1993. Effect of successive watermelon plantings on Fusarium oxysporum and other microorganisms suppressive and conducive to Fusarium wilt of watermelon. Phytopathology 83:1097-1105.

20. Larkin, R. P., Hopkins, D. L., and Martin, F. N. 1996. Suppression of Fusarium wilt of watermelon by nonpathogenic Fusarium oxysporum and other microorganisms recovered from a disease-suppressive soil. Phytopathology 96:812-819.

21. Latour, X., Corberand, T., Laguerre, G., Allard, F., and Lemanceau, P. 1996. The composition of fluorescent pseudomonad populations associated with roots is influenced by plant and soil type. Appl. Environ. Microbiol. 62:2449-2456.

22. Lemanceau, P., Corberand, T., Gardan, L., Latour, X., Laguerre, G., Boeufgras, J.-M., and Alabouvette, C. 1995. Effect of two plant species, Flax (Linum usitatissinum L.) and tomato (Lycopersicon esculentum Mill.), on the diversity of soilborne populations of fluorescent pseudomonads. Appl. Environ. Microbiol. 61:1004-1012.

23. Liu, L., Kloepper, J. W., and Tuzun, S. 1995. Induction of systemic resistance in cucumber by plant growth-promoting rhizobacteria; duration of protection and effect of host resistance on protection and root 
colonization. Phytopathology 85:1064-1068.

24. Liu, S., and Baker, R. 1980. Mechanism of biological control in soil suppressive to Rhizoctonia solani. Phytopathology 70:404-412.

25. Mazzola, M. 1997. Identification and pathogenicity of Rhizoctonia spp. isolated from apple roots and orchard soils. Phytopathology 87:582-587.

26. Mazzola, M. 1998. Elucidation of the microbial complex having a causal role in the development of apple replant disease in Washington. Phytopathology 88:930-938.

27. Mazzola, M. 1998. Towards the development of sustainable alternatives for the control of apple replant disease in Washington. Pages 8.1-8.3 in: Proc. Annu. Int. Res. Conf. on Methyl Bromide Alternatives and Emissions Reductions. Methyl Bromide Alternatives Outreach, Fresno, CA.

28. Mazzola, M. 1999. Transformation of soil microbial community structure and Rhizoctonia-suppressive potential in response to apple roots. Phytopathology 89:920-927.

29. Mazzola, M. 2000. Suppressive soils. Pages 850-851 in: The Encyclopedia of Plant Pathology. O. C. Maloy and T. D. Murray, eds. John Wiley $\&$ Sons, New York.

30. Mazzola, M., and Gu, Y.-H. 2000. Impact of wheat cultivation on microbial communities from replant soils and apple growth in greenhouse trials. Phytopathology 90:114-119.

31. Menzies, J. D. 1959. Occurrence and transfer of a biological factor in soil that suppresses potato scab. Phytopathology 49:648-652.

32. Notz, R., Maurhofer, M., Schnider-Keel, U., Duffy, B., Haas, D., and Défago, G. 2001. Biotic factors affecting expression of the 2,4-diacetylphloroglucinol biosynthesis gene phlA in Pseudomonas fluorescens biocontrol strain CHA0 in the rhizosphere. Phytopathology 91:873-881.

33. Raaijmakers, J., Weller, D. M., and Thomashow, L. S. 1997. Frequency of antibiotic-producing Pseudomonas spp. in natural environments. Appl. Environ. Microbiol. 63:881-887.

34. Scher, F. M., and Baker, R. 1980. Mechanism of biological control in a Fusarium-suppressive soil. Phytopathology 70:412-417.

35. Shiomi, Y., Nishiyama, M., Onizuka, T., and Marumoto, T. 1999. Com- parison of bacterial community structures in the rhizoplane of tomato plants grown in soils suppressive and conducive towards bacterial wilt. Appl. Environ. Microbiol. 65:3996-4001.

36. Shipton, P. J. 1975. Take-all decline during cereal monoculture. Pages 137-144 in: Biology and Control of Soilborne Pathogens. G. W. Bruehl, ed. The American Phytopathological Society, St. Paul, MN.

37. Simon, A., and Ridge, E. H. 1974. The use of ampicillin in a simplified selective medium for the isolation of fluorescent pseudomonads. J. Appl. Bacteriol. 37:459-460.

38. Smiley, R. W. 1978. Colonization of wheat roots by Gaeumannomyces graminis inhibited by specific soils, microorganisms and ammonium nitrogen. Soil Biol. Biochem. 10:175-179.

39. Smith, K. P., Handelsman, J., and Goodman, R. M. 1997. Modeling doseresponse relationships in biological control: Partitioning host responses to the pathogen and biocontrol agent. Phytopathology 87:720-729.

40. Smith, K. P., Handelsman, J., and Goodman, R. M. 1999. Genetic basis in plants for interactions with disease suppressive bacteria. Proc. Natl. Acad. Sci. USA 96:4786-4790.

41. Stotzky, G., and Martin, R. T. 1963. Soil mineralogy in relation to the spread of Fusarium wilt of banana in Central America. Plant Soil 18:317337.

42. Van Bruggen, A. H. C. 1995. Plant disease severity in high-input compared to reduced-input and organic farming systems. Plant Dis. 79:976983.

43. Vidaver, A. K. 1967. Synthetic and complex media for the rapid detection of fluorescence of phytopathogenic pseudomonads: Effect of the carbon source. Appl. Microbiol. 15:1523-1524.

44. Westphal, A., and Becker, J. O. 1999. Biological suppression and natural population decline of Heterodera schachtii in a California field. Phytopathology 89:434-440.

45. Workneh, F., van Bruggen, A. H. C., Drinkwater, L. E., and Shennan, C. 1993. Variables associated with corky root and Phytophthora root rot of tomatoes in organic and conventional farms. Phytopathology 83:581-589. 